\title{
The Role of Education in Pakistan: Millennium Development Goal
}

\author{
Fahad Ahmed Qureshi ${ }^{1} \&$ Muhammad Asad Ullah Moavia ${ }^{2} \&$ Mubeen Butt $^{3}$
}

\author{
${ }^{1}$ Arizona State University, Boston, United States of America \\ ${ }^{2}$ University of Lahore, Lahore, Pakistan \\ ${ }^{3}$ Minhaj University Lahore, Lahore, Pakistan \\ Correspondence: Fahad Ahmed Qureshi, Boston, United States of America. \\ Email: muftifaqureshi@gmail.com
}

Received: January 9, 2019

Accepted: February 15, 2019

Online Published: March 1, 2019

doi: 10.23918/ijsses.v5i3p60

\begin{abstract}
Epicurus a "Greek Philosopher" argued that death is a good thing for a person who is deprived of good things in life such as social justice, employment and education. Shally Kagan accepted the philosophy of Epicurus in his death book, though, he provides a solution. He said in his book that bad things in life can be mitigated with psychological factor amnesia. If we glimpse over historical perspective for Pakistan then, Epicurus argument would be convincing for layman about death is a good thing- because in Pakistan people are deprived of good things in life. Pakistani people were victims of bad things such as suicidal attacks, natural disasters and unemployment after 2000. Nevertheless, in this paper we gave different solution than Kagan Shally for Epicurus death dispute. We follow World Bank Millennium development goal second "Education" and (Egloff, 2014) psychological rationale; that explain violence prevention is a means to be applied in early childhood education. Education is the only way of socio-emotional learning such as suicidal attacks and gives us a solution of bad things that turn out to our lives. Combining World Bank MDG's aim and (Egloff, 2014) thesis; we can preserve happiness and prosperity for Pakistani citizens if we register our young generation to public schools.
\end{abstract}

Keywords: ARDL, Education, Death, Social Injustice

\section{Introduction}

Epicurus argument about the death has been formulated with three main points, "Something can be bad for you only if you exist", "When you are dead you don't exist", "Death can't be bad for you". He justifies his argument that death is a good thing for you only if you are deprived of good things in life. In this paper we are analyzing developing country Pakistan. Pakistan is rich in agriculture sector, however industrial sector is not good due to lack of technology and human development. So, mostly people rely on agriculture rather than industrial and service sector. Government of Pakistan pays little attention on education due to budgetary constraints. Pakistan was a peaceful country before 2000 and employment opportunities were reasonable, yet suddenly Pakistan came into power of violence such as social injustice $^{1}$, unemployment, political instability ${ }^{2}$ natural disasters ${ }^{3}$ and brutal suicidal attacks. These bad

\footnotetext{
${ }^{1}$ Social injustice is the terrain of selfishness and dishonesty to poor's by rich families (Mohsin \& Zaman, 2012); that have privileged in our daily lives and ruined our social structure of common goods. Another study done by (Bomyea, et al., 2013) show that social injustice create presence of depression and mental health related impairment such as anxiety (Iverach, Menzies, \& Menzies, 2014) that are the possible factor of violence activities
} 
things in life create interpersonal violence. Zimmerman and Posick (2014) explain that suicidal behaviour is likely to engage in interpersonal violence but interpersonal are unlikely to engage in suicidal attacks. However, we are not certain whether human developments in Chicago neighbourhoods' results are valid in case of Pakistan. Political analyst ${ }^{4}$, law enforcement agencies ${ }^{5}$ and policy makers are trying to mitigate brutal suicidal attacks and to enhance employment opportunities for Pakistani citizens. However, this effort is not a persuasive effort as compared to developed countries like USA. USA is always trying to support Pakistan to mitigate terrorism and to enhance employment opportunities. Pakistan has paid heavy economic cost of these vicious suicidal attacks in tourism sector ${ }^{6}$, industrial sector, airline sector ${ }^{7}$ and financial markets although much effort has been done by USA and Pakistan law enforcement agencies. World bank has given a solution to bad things in life - promotion of education $^{8}$. Limited attention has been paid to education for Pakistan after 2000. Research priorities have focused on- poverty ${ }^{9}$, weak and falling states; socio-political conflict such as wrong foreign policies and clash of civilization and religiosity factor such as madrasas (Rice, 2009). In this paper we only focus on education sector of Pakistan. For this reason we follow rationale about education and World Bank second target "Education" (Egloff, 2014).

\section{Literature Review}

In this section we will discuss about empirical evidence concerning suicidal attacks. We will also discuss the impact of education on economy which is solution to violence and bad things in life. In order to integrate historical perspective, there are psychological, sociological, economical and anthropological concepts necessary in order to understand the global terrorism dilemma such as bomb blasting. We have divided literature review into two parts. In the first part, we will briefly discuss psychiatric response of violence for terrorism. In next part, we will talk about socio-political response of violence and solution

such as terrorist attacks. However, clinical criteria may limit generalizability of violence response in evaluation of co-morbidity.

${ }^{2}$ The distributional characteristic of meat, fruit, soft drinks and all ready- made food products are low that implies expenditure on these products are evenly distributed over total expenditures which favours rich families (Mohsin \& Zaman, 2012). political instability have effected in Pakistan due to low purchasing power of a consumer because of inflation (Khan \& Saqib, 2011; Shahbaz, 2013).

${ }^{3} \mathrm{I}$ am attaching a reference about disasters that occurs in Pakistan "The Brookings institution London School of Economics Project on Internal Displacement" (Ferris, Petz, \& Stark, 2013).

${ }^{4}$ Suicide is not a biological factor but a psycho-social factor (Goldney, 2003). From 2001 to up till now, Pakistan has been facing a crucial time of suicidal attacks, social disorder, religion misunderstanding, unemployment and other geo-political problems (Faruqui \& Afghan, 2011).

${ }^{5}$ Although significant efforts have been done by law enforcement agencies of any country. However the most important policy implication is working towards terrorism under core strategies can be beneficial for any country (Pelfrey Jr, 2007)

${ }^{6}$ Terrorist activities shock to tourist industry and change the image profile of destination (Araña \& León, 2008).

7 (Price \& Forrest, 2013) show that airline sector can be secured from terrorism if prime target for attack with airports enduring more risk on violence.

${ }^{8}$ Education is the only factor that bring research and development in any country. Koh (2007) explains that an allocation of research and development can combat real terrorism.

${ }^{9}$ Poverty is one of the most important indicator that brings terrorism activities. Barros, Faria and Gil-Alana (2008) studied terrorist attacks against USA citizens in Africa from 1978-2002 using ITERATE data set. They found that terrorist attacks to USA citizens in Africa are persistent and perpetuated due to poverty and low level of economic and political freedom. 
with nature to educational policy. We will also examine empirical evidences for curbing terrorist activities. The control of terrorist activities leads to economic growth.

Now we discuss psychiatric response of violence. Potential physical condition and debilitating mental health are the main factors of suicidal attacks and violence and hence are responsible for every terrorist activities (DiMaggio, Madrid, Loo, \& Galea, 2008; Loza, 2007; Valentiner, Gutierrez, \& Blacker, 2002; Evans, Hawton, \& Rodham, 2004; Gupta, Avasthi, Grover, \& Singh, 2014; Cleary, 2012; Bader \& Schuster; Somerville, Purcell, \& Morrison, 2011; Wali, Sritharan, Mehes, Abdullah, \& Rasheed, 2014; Fremont, Pataki, \& Beresin, 2005; Hayes, 2002). Bograkos (2012) discusses that there is close relationship between international terrorism and transnational organized crimes such as illicit drugs, money laundering, illegal arms trafficking and illegal movement of nuclear armaments. He studied narco-trafficking and terrorism. He showed that heroin is the main factor that causes violence. He discusses that Afghanistan, Pakistan, Iran and Turkey are the heroin epicentre of Golden crescent that supply $90 \%$ of the World heroin.

Here are some evidences that show with financing on counter-terrorism activities leads to economic growth. Shahbaz, Shabbir, Malik and Wolters (2013) investigate the terrorism and economic growth for Pakistan using ARDL bounds approach. The study indicates that there is long run positive relationship between spending on terrorism activities and economic growth. Other studies (Gupta, Clements, Bhattacharya, \& Chakravarti; Malik \& Zaman, 2013; Shahbaz, 2013; Ismail \& Amjad, 2014) count that spending on counter terrorism increases economic growth.

Ehrlich (1975) shows that education has negative relationship with crime activities. He postulates that probability of punishment and length of imprisonment, education would bias relative opportunities away crimes against poverty. He shows there is positive relationship between crime against poverty and income inequality while crime has negative relationship with education. Benmelech and Berrebi (2007) show that human capital is an important factor in the production of terrorism activities. They show that older and educated suicide bombers are being assigned by their terror organization to more important targets. Krueger and Maleckova (2002) show causal relationship between poverty or low level of education and participation in politically motivated violence and terrorist activities. They show that there is positive relationship between education and participation in terrorist organization to do more crimes. Berman and Laitin (2008) demonstrate that crime and violence can be mitigated through the provision of public goods under club model.

The mitigation of terrorism risk is based on dynamic interaction between terrorist organizations and governments with asymmetric information. Uncertainties in the objectives and capabilities of terrorists complicate defensive resource allocation for general public safety. The government can detect implicit and explicit signals to support decisions and update its belief after receiving terrorist threats. However, optimal government strategy will significantly impact the action of terrorists (Jing, Shen, \& Rui, 2010). 


\section{Theoretical Justification for Model}

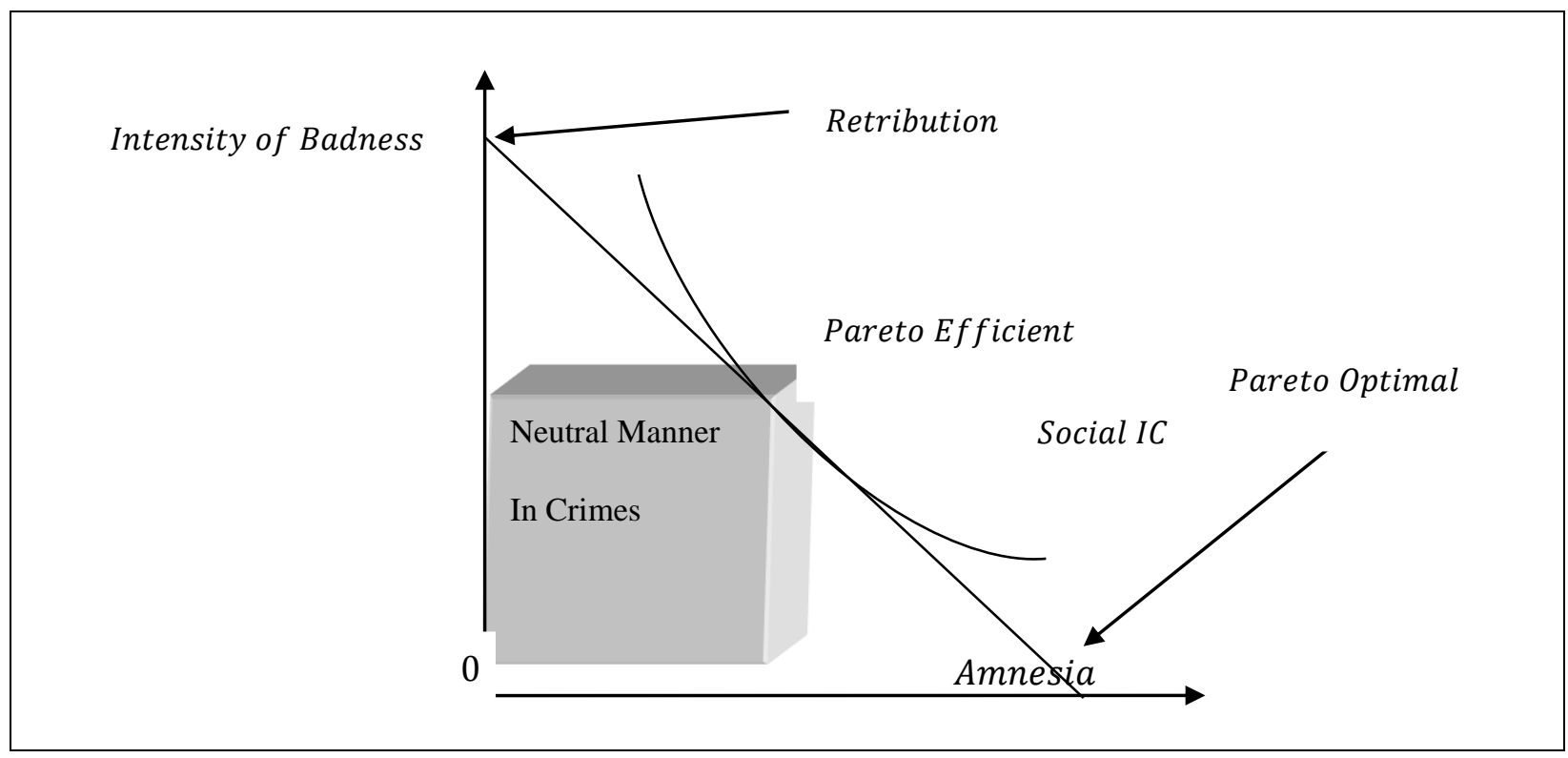

Figure 1: Professor Shelly Cagan Philosophical Argument about Removal of Badness in Life

Kagan (2012) explains in his "Death" book that "Death" is the concept of immortality. Immortality theory is a philosophical theory that is explained in different religious books such as in Holy Bible and in Holy Quran in which God says that after doomsday you will live forever. Living forever is something unimpressive when we think for our daily lives. Immortality theory does not hold valid in economic "Utility" theory. Theory of utility explains that getting one glass of water gives you better utility than getting second glass of water and so on ${ }^{10}$. After doomsday living 100 years will give you more utility of enjoyment than in next 200 years and so on. Kagan clarifies that immortality theory can be valid with Utility theory in economics by combing the psychological idea of amnesia. Immortality is a paramount for you only if you forget your past (amnesia) and start again new life after amnesia. In the above figure I am justifying Professor Shally Kagan's argument about amnesia in life. There is a negative relationship between level of amnesia and intensity of badness in life such as incurable diseases in life, social injustice, unemployment, natural disasters, political violence and suicidal attacks. At maximum level of amnesia gives you zero level of badness in life and vice versa. Maximum level of amnesia gives you a Pareto optimal point in which you (Patient) are completely worse off as you are unable to work and become (parasite) burden to economy and hence cannot contribute to economy. Pareto's efficient point claims that there must be half level of amnesia and half level of intensity of badness. If you are 100\% responsive of your badness in your life that gives you pain in your life, then you are in a condition of retribution. Well, to allege about amnesia that reduces badness in your life is not a sophisticated claim. Human being is impulsive and you cannot have surety that a usual person is not happy in his/her life and hence he is violent. So in order to remove his/her badness in life, you wish to damage his/her

${ }^{10}$ For better understanding, We would like you to read any introductory microeconomic book and to read consumption and utility theory. It would give you better understanding about utility theory, law of diminishing marginal utility and law of diminishing marginal return. 
hippocampus for attaining amnesia. This is not a realistic and permissible explanation that to remove badness in life; you need to damage human brain hippocampus part. If you are powerless to find a right person who has a badness in his/her life, then it is pleasing to achieve maximum target by damaging all society hippocampus. Let us change our preposition with rational decision of millennium development goal and secondly "Education" and educate the whole society in order to make it peaceful.

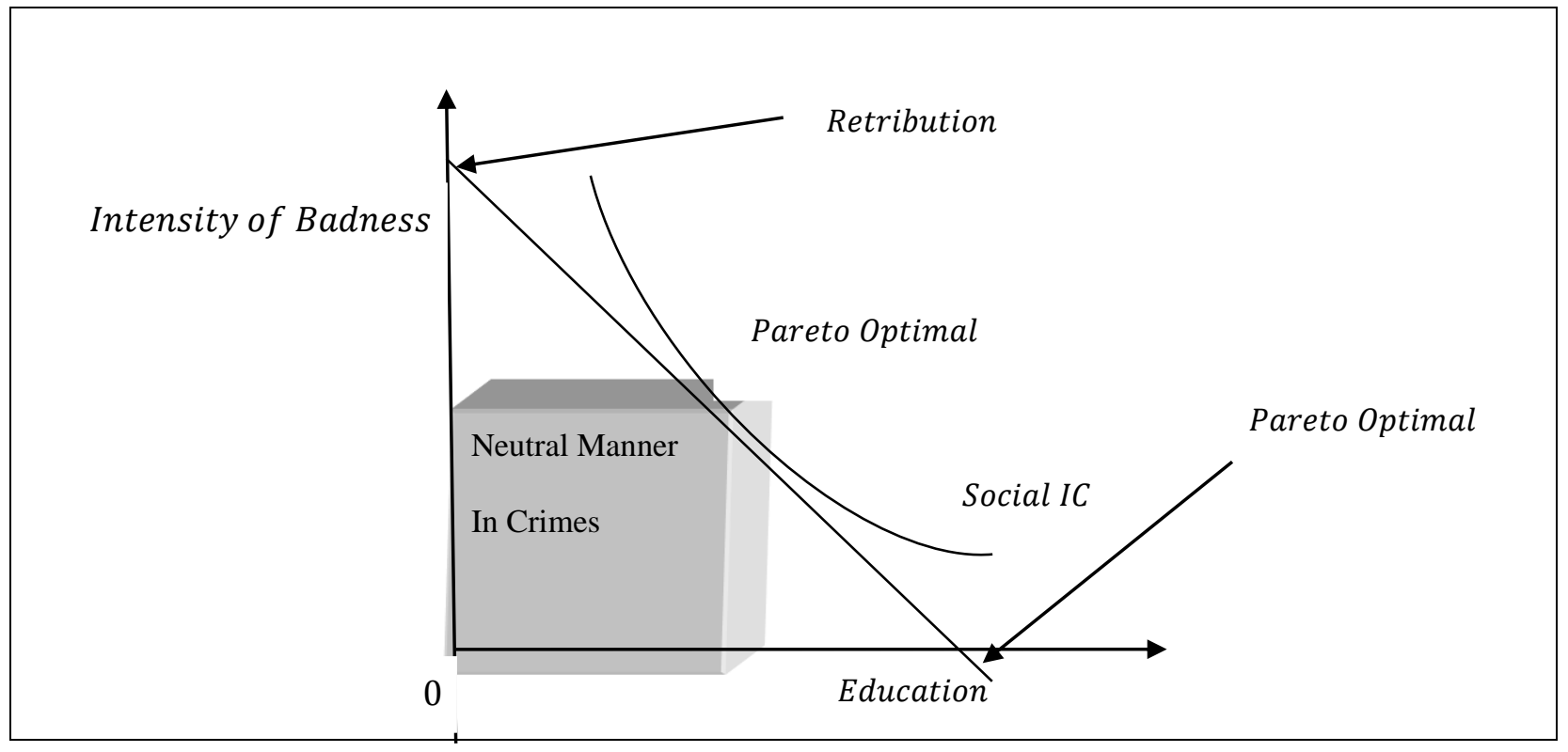

Figure 2: Millennium Development Goal target (2025) by Stanford University

World Bank bestows its efforts with targeted millennium development goals till 2025. The task is assigned to Stanford University through different resources with the help of Daphne Koller and Andrew $\mathrm{Ng}$ (Stanford University). The eventual plan of World bank is to control population for developing and underdeveloped countries, to reduce HIV/AIDS, to make for young generation an employment program, voting in community and gain access to credit ((Burnett, 2012); (Burnett \& Felsman, 2012)). Education and intensity of badness have negative relationship. As level of education increases, it makes a man more rational and fruitful for society. Zero stage of education generates intensity of badness such as unemployment and burden to economy. Economic benefits with reduction in poverty is possible only if we educate our citizens and target (MDG's) goal [2] till 2025 (Jafarey, Kamal, Qureshi, \& Fikree, 2008). Education is one of the main perspectives that possibly brings happiness for Pakistani generation. Pakistan is not a rich country, however if we utilize donor aid and provide primary education, we can achieve MDG's target for 2025 as well as we can neutralize manners in crime activities such as suicidal attacks.

\section{Data Sources and Methodology}

The data extracted for the regression analysis from world development index (WDI) and central bank of Pakistan. The data is used for the period of 1984 to 2013. We use ARDL approach for co-integration among variables. 
1. Log GDP in US dollar

2. Public spending on education \% of GDP in US dollar; Education Spending as a proxy for human capital (HC)

3. Physical Capital in US dollar; Physical Capital (PC)

4. Binary indicator for Suicidal attacks (i.e. Zero with no suicide attacks whereas one with suicide attacks for Pakistan)

5. Aid from foreign countries in US dollar

\section{Results and Discussion}

Table 1: Unit Root Test for the Data

\begin{tabular}{llllcl}
\hline Variable & Test & Deterministic Term & T-Value & 5\% Critical Value & Order \\
\hline GDP & ADF & None & -1.954 & 0.0403 & 2 \\
Aid & ADF & Constant & -3.584 & 0.0015 & 1 \\
HC & ADF & Constant & -2.974 & 0.0598 & 0 \\
PC & ADF & None & -1.954 & 0.0000 & 1 \\
\hline
\end{tabular}

Note: Critical values are taken from Davidson and Mackinnon (1993)

Our data is time series in nature. For this reason, we have to make a clear adjustment process for nonstationary data into stationary series. For this reason, we apply ADF test to show whether the data is stationary or not (Dickey \& Fuller, 1979). We can see in the above table that all the variables have different order of integration. In order to find long run co-integration relationship, we apply Autoregressive distributed lag model (ARDL) for this analysis. For lag length criteria among variables we choose AIC and BSC.

The ARDL bounds testing approach to co-integration involves the unrestricted error correction model (UECM) as follows:

$$
\begin{aligned}
& \Delta A I D_{t}= \\
& \varphi_{0}+\varphi_{1} T+\varphi_{2} \ln G D P_{t-1}+\varphi_{3} P C_{t-1}+\varphi_{4} H C_{t-1}+\varphi_{5} A I D_{t-1}+\sum_{i=1}^{p} \varphi_{i} \Delta \ln G D P_{t-i}+ \\
& \sum_{j=0}^{q} \varphi_{i} \Delta H C_{t-i}+\sum_{k=0}^{r} \varphi_{i} \Delta P C_{t-i}+\sum_{l=0}^{m} \varphi_{i} \Delta A I D_{t-i}+\mu_{i} \\
& \Delta \ln G D P_{t}= \\
& \alpha_{0}+\alpha_{1} T+\alpha_{2} \ln G D P_{t-1}+\alpha_{3} P C_{t-1}+\alpha_{4} H C_{t-1}+\alpha_{5} A I D_{t-1}+\sum_{i=1}^{p} \alpha_{i} \Delta \ln G D P_{t-i}+ \\
& \sum_{j=0}^{q} \alpha_{i} \Delta H C_{t-i}+\sum_{k=0}^{r} \alpha_{i} \Delta P C_{t-i}+\sum_{l=0}^{m} \alpha_{i} \Delta A I D_{t-i}+\mu_{i} \\
& \Delta P C_{t}=\beta_{0}+\beta_{1} T+\beta_{2} \ln G D P_{t-1}+\beta_{3} P C_{t-1}+\beta_{4} H C_{t-1}+\beta_{5} A I D_{t-1}+\sum_{i=1}^{p} \beta_{i} \Delta \ln G D P_{t-i}+ \\
& \sum_{j=0}^{q} \beta_{i} \Delta H C_{t-i}+\sum_{k=0}^{r} \beta_{i} \Delta P C_{t-i}+\sum_{l=0}^{m} \beta_{i} \Delta A I D_{t-i}+\mu_{i} \\
& \Delta H C_{t}=\gamma_{0}+\gamma_{1} T+\gamma_{2} \ln G D P_{t-1}+\gamma_{3} P C_{t-1}+\gamma_{4} H C_{t-1}+\gamma_{5} A I D_{t-1}+\sum_{i=1}^{p} \gamma_{i} \Delta \ln G D P_{t-i}+ \\
& \sum_{j=0}^{q} \gamma_{i} \Delta H C_{t-i}+\sum_{k=0}^{r} \gamma_{i} \Delta P C_{t-i}+\sum_{l=0}^{m} \gamma_{i} \Delta A I D_{t-i}+\mu_{i}
\end{aligned}
$$


The intercept and trend component are shown with $\alpha, \beta, \gamma, \varphi$ and $\varphi_{1} T, \alpha_{1} T, \beta_{1} T, \gamma_{1} T$. The next argument for these equations is to compute F-statistics and compare it with the tabulated values of critical bounds shown in (Pesaran, Shin, \& Smith, 2001). The null hypothesis of no-co-integration relationship of 4 models with $H_{0}: \alpha_{2}=\alpha_{3}=\alpha_{4}=\alpha_{5}=0 ; H_{0}: \beta_{2}=\beta_{3}=\beta_{4}=\beta_{5}=0 ; H_{0}: \gamma_{2}=\gamma_{3}=\gamma_{4}=\gamma_{5}=0$; $H_{0}: \varphi_{2}=\varphi_{3}=\varphi_{4}=\varphi_{5}=0$. The null hypothesis can be tested with alternate hypothesis of $H_{1}: \alpha_{2}=$ $\alpha_{3}=\alpha_{4}=\alpha_{5} \neq 0 ; H_{1}: \beta_{2}=\beta_{3}=\beta_{4}=\beta_{5} \neq 0 ; \quad H_{1}: \gamma_{2}=\gamma_{3}=\gamma_{4}=\gamma_{5} \neq 0 ; \quad H_{1}: \varphi_{2}=\varphi_{3}=\varphi_{4}=$ $\varphi_{5} \neq 0$. The decision is made on the following bases if F-statistic value is more than upper critical bound we reject the hypothesis of no co-integration relationship and vice versa.

Table: 2 Short Run Estimates of ARDL Model

\begin{tabular}{lccc}
\hline Regressor & Coefficient & Standard Error & Probability \\
\hline$\beta_{0}$ & 0.0073 & 0.0245 & 0.0086 \\
$\Delta L G D P_{t-1}$ & -0.479 & 0.0489 & 0.0332 \\
$\Delta P C$ & -0.001 & 0.0034 & 0.7633 \\
$\Delta H C$ & 0.1191 & 0.0125 & 0.0352 \\
$\Delta H C_{t-1}$ & 0.0274 & 0.0145 & 0.0776 \\
$\Delta A I D_{t-1}$ & -0.002 & 0.0154 & 0.0091 \\
$\Delta A I D$ & 0.0019 & 0.0167 & 0.9011 \\
$\Delta E C_{t-1}$ & -0.6874 & 0.0574 & 0.0001 \\
\hline
\end{tabular}

Long Run Estimates ARDL Lag

$$
\begin{gathered}
G D P^{*}{ }_{t}=\alpha_{1}+b_{1} P C_{t}^{*}+c_{1} H C_{t}^{*}+d_{1} A I D_{t}^{*}+\mu_{1} \\
G D P^{*}{ }_{t}=\left[\begin{array}{c}
4.171 \\
(0.07)
\end{array}\right]-\left[\begin{array}{c}
0.019 \\
(0.03)
\end{array}\right] A I D_{t}^{*}+\left[\begin{array}{c}
0.344 \\
(0.0013)
\end{array}\right] H C_{t}^{*}+\left[\begin{array}{c}
0.455 \\
(0.225)
\end{array}\right] P C_{t}^{*}+\mu_{1}
\end{gathered}
$$

Final Regression Model

$$
\begin{gathered}
G D P^{*}{ }_{t}=\left[\begin{array}{c}
13.96 \\
(0.00)
\end{array}\right]+\left[\begin{array}{c}
0.144 \\
(0.0193)
\end{array}\right] H C_{t}+\left[\begin{array}{c}
0.003 \\
(0.281)
\end{array}\right] P C_{t}-\left[\begin{array}{c}
0.235 \\
(0.025)
\end{array}\right] \text { Aid }_{t} \\
-\left[\begin{array}{c}
0.0574 \\
(0.000)
\end{array}\right] \text { Suicide Attacks } t+\left[\begin{array}{c}
0.0089 \\
(0.008)
\end{array}\right] H C * \text { Aid }_{t}+\mu_{1} \\
R^{2}=0.809 ; D-\text { Watson }_{\text {Test }}=2.007 ; \text { LM }_{\text {Test }}\left[\begin{array}{c}
(1.658) \\
0.211
\end{array}\right] ; \chi^{2} \text { Normal }_{\text {Test }}\left[\begin{array}{c}
(1.233) \\
0.239
\end{array}\right]
\end{gathered}
$$

There is long run co-integration relationship among HC, PC, Aid and LGDP with (Pesaran, Shin, \& Smith, 2001) bound test value. The critical value is more than upper critical bound and we have cointegration relationship among variables. Error correction term has negative significant sign that defines the convergence in the long run among the variables. Aid and physical capital have no short run relationship with LGDP while human capital and the lag term of foreign aid have short run relationship with LGDP. In the long run aid is negatively linked with LGDP whereas human capital has significant 
positive association with LGDP. Physical capital has no appeal in the long run with GDP. The regression estimates show that human capital have much worth with economic growth. It contributes to the economy with 0.144 percent of GDP. Physical capital does not have much impact and hence has a positive insignificant relationship. We see similar results in a study conducted by Blomberg, Hess and Orphanides (2004) who found that suicidal attacks (terrorist activities) have negative relationship with GDP. In our case suicidal attack is negatively related with GDP while human capital is positively linked with GDP. Our results go with Baldacci, Clements, Gupta and Cui, (2004) who demonstrate human capital is positively linked with GDP. Aid does not contribute to the GDP, however, if we make our contemplation of donor's countries aid with moderation effect of (HC*AID) then it contributes positively to the economy for our case. There is no serial correlation and $R^{2}$ which are significant with no variance inflation factor greater than 5. Our intention is not to show any heavy econometric model, but to show the MDG's goal [2] worth with reference to Pakistan that is true and suicidal attack has negative relationship with GDP. Pakistan can have an effective economic growth and low revenge in suicidal attack if Pakistan contributes positively and significantly to education level. We see similar results in Freytag, Krüger, Meierrieks and Schneider, (2011) who showed that poor socio-economic development is conducive for terrorism.

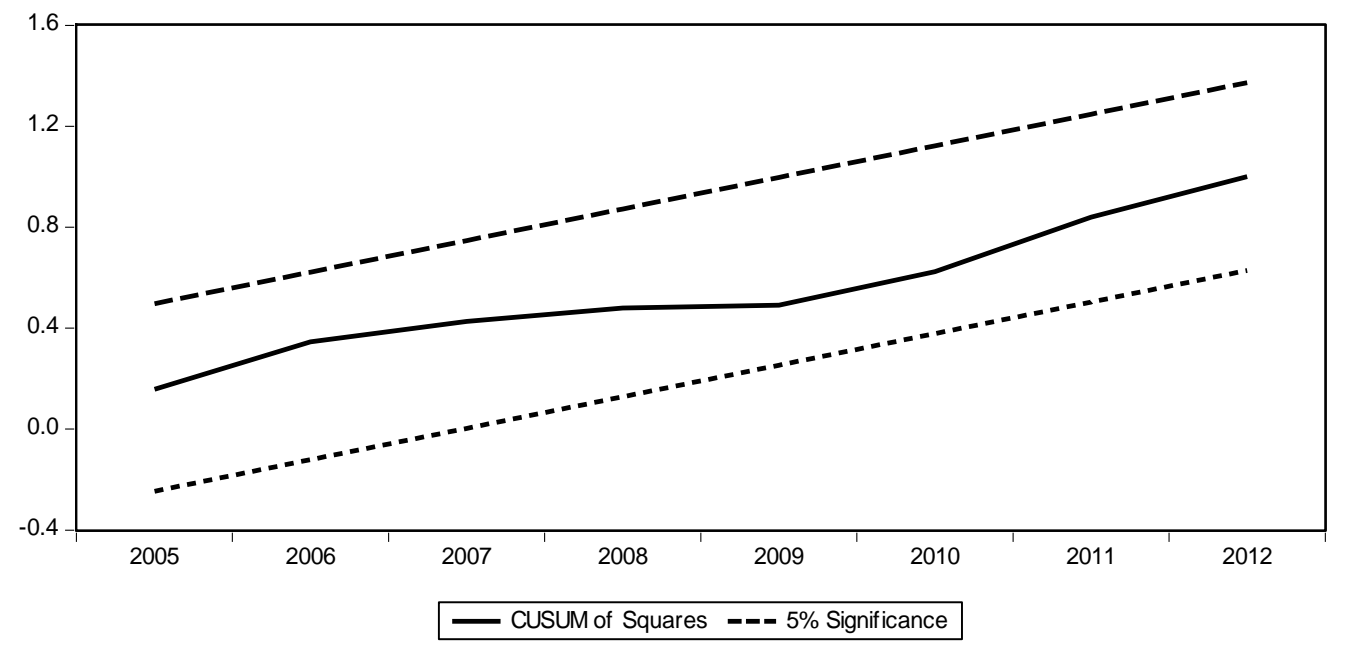

Figure 3: Stability Test

The graph of CUSUM of square indicates that the model is stable and has a worth in the economy for policy making in Pakistan. In our above regression analysis we have showed the economic impact of education with economic growth and suicidal attack in Pakistan. Many people in Pakistan oppose western education system and consider Islamic education is the ultimate education for our spiritualism and for mundane life. For this reason, Pakistan have shaped different madrasas and militant Islamic fundamentalism. Western media have made an attempt to indict madrasas as a genesis of violent Islamic radicalization. Western media often show their work based on guesswork, misinterpret and ignore the history of Pakistan (McClure, 2009) such as social injustice and suicidal attacks which prevailed 20042014 at horrified level (Andrabi, Das, Fair, \& Khwaja, 2009). 


\section{Conclusion}

In this paper we gave a different solution than Kagan Shally for Epicurus death dispute. We followed World Bank Millennium development Goal second "Education" and (Egloff, 2014) psychological rationale; that explains violence prevention is a means to be applied in early childhood education. In order to reduce bad things in life such as terrorist activities, unemployment and social injustice, education is the only way of socio-emotional learning. Combining World Bank MDG's aim and (Egloff, 2014) thesis; we can preserve happiness and prosperity for Pakistani citizens if we register our young generation to public schools.

MDG's goal [2] for 2025 is an ultimate solution and hence, brought our citizens happiness. If we educate our people in public schools we can achieve and increase GDP. Many people in Pakistan oppose western education system and consider Islamic education is the ultimate education for our spiritualism and for mundane life. For this reason, Pakistan have shaped different madrasas and militant Islamic fundamentalism. Western media have made an attempt to indict madrasas as a genesis of violent Islamic radicalization. Western media often shows their work based on guesswork, misinterpret and ignore the history of Pakistan (McClure, 2009) such as social injustice and suicidal attacks from 2004-2014 at horrified level. Suicidal attacks have negative relationship with GDP. MDG's [2] goal says that it is important to contribute in the economy in the form of human capital that will increase GDP as explained by (Freytag, Krüger, Meierrieks, \& Schneider, 2011). In our case suicidal attacks are negatively related with GDP while human capital is positively linked with GDP. Our results are similar with (Baldacci, Clements, Gupta, \& Cui, 2004) and demonstrate that human capital is positively related with GDP.

\section{References}

Andrabi, T., Das, J., Fair, C. C., \& Khwaja, A. I. (2009). The Madrasa Myth. Foreign Policy, 1-2. Araña, J. E., \& León, C. J. (2008). The impact of terrorism on tourism demand. Annals of Tourism Research , 35 (2), 299-315.

Bader, B., \& Schuster, T. (n.d.). Expatriate Social Networks in Terrorism-Endangered Countries: An Empirical Analysis in Afghanistan, India, Pakistan, and Saudi Arabia. Journal of International Management, 2014.

Baldacci, E., Clements, B., Gupta, S., \& Cui, Q. (2004). Social Spending, Human Capital, and Growth in Developing Countries: Implications for Achieving the MDGs. IMF Working Paper $W P / 04 / 217$.

Barros, C. P., Faria, J. R., \& Gil-Alana, L. A. (2008). Terrorism against American citizens in Africa: Related to poverty? Journal of Policy Modeling , 30 (1), 55-69.

Benmelech, E., \& Berrebi, C. (2007). Attack Assignments in Terror Organizations and The Productivity of Suicide Bombers. NBER Working Paper No. 12910 .

Berman, E., \& Laitin, D. D. (2008). Religion, terrorism and public goods: Testing the club model. Journal of Public Economics , 92 (10-11), 1942-1967.

Blomberg, S. B., Hess, G. D., \& Orphanides, A. (2004). The macroeconomic consequences of terrorism. Journal of Monetary Economics , 51 (5), 1007-1032.

Bograkos, W. (2012). Convergence: a review of narco-terrorism for the osteopathic family physician. Osteopathic Family Physician, 4 (2), 48-54.

Bomyea, J., Lang, A. J., Craske, M. G., Chavira, D., Sherbourne, C. D., Rose, R. D., et al. (2013). Suicidal ideation and risk factors in primary care patients with anxiety disorders. Psychiatry Research, 209 (1), 60-65. 
Burnett, N. (2012). A Learning Goal for Education? Scoping for MDG2 Post-2015. Washington: Results for Development Institute.

Burnett, N., \& Felsman, C. (2012). Post-2015 Education MDGS. Overseas Development Institue , 1-28.

Cleary, A. (2012). Suicidal action, emotional expression, and the performance of masculinities. Social Science \& Medicine , 74 (4), 498-505.

Dickey, D. A., \& Fuller, W. A. (1979). Distribution of the estimation for autoregressive time series with a unit root.Journal of the American Statistical Association, 355-367.

DiMaggio, C., Madrid, P. A., Loo, G. T., \& Galea, S. (2008). The Mental Health Consequences of Terrorism: Implications for Emergency Medicine Practitioners. The Journal of Emergency Medicine, 35 (2), 139-147.

Egloff, G. (2014). Violence prevention and beyond - Theses on the spirit of terrorism. Egyptian Journal of Forensic Sciences , 1-7.

Ehrlich, I. (1975). On the Relation between Education and Crime. National Bureau of Economic Research, 0-07-010068-3, 313 - 338.

Evans, E., Hawton, K., \& Rodham, K. (2004). Factors associated with suicidal phenomena in adolescents: A systematic review of population-based studies. Clinical Psychology Review , 24 (8), 957-979.

Faruqui, R., \& Afghan, S. (2011). P03-445 - Suicide risk awareness in Pakistan: Influence of religious, cultural, legal, socio-economic and interpersonal factors. European Psychiatry, 26.

Fremont, W. P., Pataki, C., \& Beresin, E. V. (2005). The Impact of Terrorism on Children and Adolescents: Terror in the Skies, Terror on Television. Child and Adolescent Psychiatric Clinics of North America , 14 (3), 429-451.

Freytag, A., Krüger, J. J., Meierrieks, D., \& Schneider, F. (2011). The origins of terrorism: Crosscountry estimates of socio-economic determinants of terrorism. European Journal of Political Economy, 27, S5-S16.

Goldney, R. D. (2003). A novel integrated knowledge explanation of factors leading to suicide. New Ideas in Psychology, 21, 141-146.

Gupta, G., Avasthi, A., Grover, S., \& Singh, S. M. (2014). Factors associated with suicidal ideations and suicidal attempts in patients with obsessive compulsive disorder. Asian Journal of Psychiatry, $12,140-146$.

Gupta, S., Clements, B., Bhattacharya, R., \& Chakravarti, S. (n.d.). Fiscal Consequences of Armed conflict and Terrorism in Low and Middle Income Countries. IMF working Paper WP/O2/142, 2002.

Hayes, e. a. (2002). Continuing education quiz: Prejudice, terrorism, and behavior therapy. Cognitive and Behavioral Practice, 9 (4), 328-329.

Ismail, A., \& Amjad, S. (2014). Determinants of terrorism in Pakistan: An empirical investigation. Economic Modelling , 37, 320-331.

Iverach, L., Menzies, R. G., \& Menzies, R. E. (2014). Death anxiety and its role in psychopathology:Reviewing the status of a transdiagnostic construct. Clinical Psychology Review , 34, 580-593.

Jafarey, S., Kamal, I., Qureshi, A. F., \& Fikree, F. (2008). Safe motherhood in Pakistan. International Journal of Gynecology and Obstetrics , 102, 179-185.

Jing, Z., Shen, S., \& Rui, Y. (2010). Asymmetric Information in Combating Terrorism: Is the Threat Just a Bluff? Tsinghua Science \& Technology , 15 (5), 604-612.

Kagan, S. (2012). Death. Yale University Press.

Khan, S. U., \& Saqib, O. F. (2011). Political instability and inflation in Pakistan. Journal of Asian Economics, 22, 540-549.

Koh, W. T. (2007). Terrorism and its impact on economic growth and technological innovation. 74 (2), $129-138$. 
Krueger, A. B., \& Maleckova, J. (2002). Education, Poverty, Political Violence and Terrorism: Is There a Causal Connection? NBER Working Paper No. 9074 .

Loza, W. (2007). The psychology of extremism and terrorism: A Middle-Eastern perspective. Aggression and Violent Behavior, 12 (2), 141-155.

Malik, Z., \& Zaman, K. (2013). Macroeconomic consequences of terrorism in Pakistan. Journal of Policy Modeling , 35 (6), 1103-1123.

McClure, K. R. (2009). Madrasas and Pakistan's education agenda: Western media misrepresentation and policy recommendations. International Journal of Educational Development , 29 (4), 334341.

McMahan, J. (2002). The Ethics of Killing: Problems at the Margins of Life. OXFORD UNIVERSITY PRESS .

Mohsin, A., \& Zaman, K. (2012). Distributional effects of rising food prices in Pakistan:Evidence from HIES2001-02 and 2005-06 survey. Economic Modelling , 29, 1986-1995.

Pelfrey Jr, W. V. (2007). Local law enforcement terrorism prevention efforts: A state level case study. Journal of Criminal Justice , 35 (3), 313-321.

Pesaran, M. H., Shin, Y., \& Smith, R. J. (2001). Bounds testing approaches to the analysis of level relationships. Journal of Applied Econometrics , 16 (20), 289-326.

Price, J. C., \& Forrest, J. S. (2013). Crime and Terrorism in Aviation: A Retrospective. Practical Aviation Security , 41-89.

Rice, S. K. (2009). Emotions and terrorism research: A case for a social-psychological agenda. Journal of Criminal Justice , 37 (3), 248-255.

Shahbaz, M. (2013). Linkages between inflation, economic growth and terrorism in Pakistan. Economic Modelling , 32, 496-506.

Shahbaz, M. (2013). Linkages between inflation, economic growth and terrorism in Pakistan. Economic Modelling , 32, 496-506.

Shahbaz, M., Shabbir, M. S., Malik, M. N., \& Wolters, M. E. (2013). An analysis of a causal relationship between economic growth and terrorism in Pakistan. Economic Modelling , 35, 21-29.

Somerville, I., Purcell, A., \& Morrison, F. (2011). Public relations education in a divided society: PR, terrorism and critical pedagogy in post-conflict Northern Ireland. Public Relations Review , 37 (5), 548-555.

Valentiner, D. P., Gutierrez, P. M., \& Blacker, D. (2002). Anxiety measures and their relationship to adolescent suicidal ideation and behavior. Journal of Anxiety Disorders , 16 (1), 11-32.

Wali, M. A., Sritharan, K., Mehes, M., Abdullah, F., \& Rasheed, S. (2014). Terrorism-related trauma in Africa, an increasing problem. Journal of Epidemiology and Global Health .

Zimmerman, G. M., \& Posick, C. (2014). Detecting Specialization in Interpersonal Violence Versus Suicidal Behavior. Journal of Adolescent Health , 55 (6), 810-816. 


\section{Appendix}

Table: 3 Domestic Suicide Attacks by Terrorist in Pakistan

\begin{tabular}{lccc}
\hline Suicide Attacks Period & \multicolumn{2}{c}{ Suicide Attacks Death } & Injury \\
\hline $1947-1999$ & 1 & 0 & 4 \\
$2000-2003$ & 5 & 106 & 206 \\
$2004-2014$ & 432 & 6178 & 15254 \\
\hline
\end{tabular}

Note: Domestic suicide attacks by terrorist in Pakistan information is taken from (Berman and David) in their paper "Religion, terrorism and public goods: Testing the club model" and Pakistan Body Count.

Table: 4 Money Spent on Terrorism in Pakistan (2001-2011)

\begin{tabular}{lcc}
\hline Years & Billion $\$$ & Billion Rupee \\
\hline $2001-02$ & 2.669 & 163.9 \\
$2002-03$ & 2.749 & 160.8 \\
$2003-04$ & 2.932 & 168.8 \\
$2004-05$ & 3.410 & 202.4 \\
$2005-06$ & 3.986 & 238.6 \\
$2006-07$ & 4.676 & 283.2 \\
$2007-08$ & 6.940 & 434.1 \\
$2008-09$ & 9.180 & 720.6 \\
$2009-10$ & 13.560 & 1136.4 \\
$2010-11$ & 17.830 & 1528.0 \\
Total: & 67.924 & 5036.4 \\
\hline
\end{tabular}

Source: Economic Survey of Pakistan 